\title{
Mean Platelet Volume (MPV), Platelet Distribution Width (PDW), Platelet Count and Plateletcrit (PCT) as predictors of in-hospital paediatric mortality: a case-control Study.
}

\author{
Zainab Mohammedi Golwala ${ }^{1}$, Hardik Shah ${ }^{1}$, Neeraj Gupta ${ }^{1}$, V. Sreenivas ${ }^{2}$, Jacob. M. Puliyel ${ }^{1}$
}

1. Department of Pediatrics and Neonatology, St. Stephens Hospital, New Delhi.

2. Department of Biostatistics, All India Institute of Medical Sciences, New Delhi.

\begin{abstract}
Background: Thrombocytopenia has been shown to predict mortality. We hypothesize that platelet indices may be more useful prognostic indicators. Our study subjects were children one month to 14 years old admitted to our hospital.

Aim: To determine whether platelet count, plateletcrit (PCT), mean platelet volume (MPV) and platelet distribution width (PDW) and their ratios can predict mortality in hospitalised children.

Methods: Children who died during hospital stay were the cases. Controls were age matched children admitted contemporaneously. The first blood sample after admission was used for analysis. Receiver operating characteristic (ROC) curve was used to identify the best threshold for measured variables and the ratios studied. Multiple regression analysis was done to identify independent predictors of mortality.

Results: Forty cases and forty controls were studied. Platelet count, PCT and the ratios of MPV/Platelet count, MPV/PCT, PDW/Platelet count, PDW/PCT and MPV x PDW/Platelet count x PCT were significantly different among children who survived compared to those who died. On multiple regression analysis the ratio of MPV/PCT, PDW/Platelet count and MPV/ Platelet count were risk factors for mortality with an odds ratio of 4.31 (95\% CI, 1.69-10.99), 3.86 (95\% CI, 1.53-9.75), 3.45 (95\% CI, 1.38-8.64) respectively. In 67\% of the patients who died MPV/PCT ratio was above 41.8 and PDW/Platelet count was above 3.86. In $65 \%$ of patients who died MPV/Platelet count was above 3.45 .

Conclusion: The MPV/PCT, PDW/Platelet count and MPV/Platelet count, in the first sample after admission in this case control study were predictors of mortality and could predict $65 \%$ to $67 \%$ of deaths accurately.

Keywords: SICK Score, PRISM, severity of illness scores PIM, in-hospital mortality; platelet indices.

DOI: http://dx.doi.org/10.4314/ahs.v16i2.3

Cite as: Golwala ZM, Shah H, Gupta N, Sreenivas V, Puliyel JM. Mean Platelet Volume (MPV), Platelet Distribution Width (PDW), Platelet Count and Plateletcrit (PCT) as predictors of in-hospital paediatric mortality: a Case-Control Study. Afri Health Sci 2016;16(2): 356-362. bttp://dx.doi.org/10.4314/abs.v16i2.3
\end{abstract}

\section{Introduction}

In-hospital mortality depends on the severity of the illness at the time of admission ${ }^{1}$. Severity of illness scores have been developed to predict the mortality in the Intensive Care Unit (ICU) ${ }^{2}$. Scoring systems such as the PSI (Physiologic Stability Index), PRISM score (Pediatric Risk of Mortality), SICK score (Signs of Inflammation that Can Kill) are severity of illness scores used in children ${ }^{2-5}$. In 2000 Vanderschueren and colleagues showed that

\section{Corresponding author: \\ Zainab Mohammedi Golwala, \\ Department of Pediatrics and Neonatology, \\ St.Stephens Hospital, Tis Hazari, New Delhi-110054. \\ E-mail address; zainabakbary@gmail.com}

thrombocytopenia by itself effectively predicts mortality in adults admitted in ICU and is complementary to different established scoring systems ${ }^{6}$.

In a case control study of 145 patients with sepsis and 143 controls, Guclu showed that, mean platelet volume (MPV) and platelet distribution width (PDW) were useful in diagnosis of sepsis and patients with PDW of more than $18 \%$ have a higher risk of death ${ }^{7}$.

Thrombocytopenia occurring in critically ill patients is the result of hemodilution, increased platelet consumption, increased platelet destruction (immune mechanisms $)^{8}$ and increased platelet sequestration ${ }^{9}$. Septicemia related destruction of platelets increases production and release into the peripheral blood of larger and younger platelets $^{10}$. Later, however there may be bone marrow suppression ${ }^{7}$. 
Platelet volume indices, estimated by automated blood cell analysers, show the changes that accompany the alterations in platelet counts ${ }^{11}$. Platelet parameters such as MPV and PDW (reflection of the variation of the platelet size in the circulation ${ }^{12}$ have been routinely available to the clinicians for some time. However their significance in various platelet disorders have only been studied recently ${ }^{7}$.

Septic rat models have shown that PDW and MPV increase in sepsis with appearance of large and heavy platelets in circulation ${ }^{13}$. Canine models of endotoxemia have shown that the platelet count and PCT decreased where as MPV and PDW are increased showing that platelet counts are correlated positively with PCT, but correlate negatively with MPV and PDW during early endotoxemia in $\operatorname{dog} s^{14}$.

In human studies, Nelson and Kehl reported that in acute infection there was platelet consumption and it was associated with an increase in $\mathrm{MPV}^{15}$. Becchi et al noted that MPV at an early stage of sepsis was important prognostically ${ }^{16}$. MPV increased during the admission period in those who died, compared to survivors ${ }^{16}$. In neonates with sepsis, a low platelet count and an increase in MPV has been observed by Guida et $\mathrm{al}^{17}$. Patrick et al demonstrated that neonates with late onset sepsis (bacteremia after 3 days of age) had a dramatic increase in MPV and $\mathrm{PDW}^{18}$.
We hypothesize that as the MPV and PDW increase and platelet count and PCT decrease in sick children, intuitively, the ratio of MPV to PCT; MPV to Platelet count, PDW to PCT, PDW to platelet count and the ratio of the product of MPV and PDW to the product of PCT and platelet count could be candidate markers of severity of illness and that these may be useful to predict mortality. To the best of our knowledge these ratios have not been studied in children in this context. We did this preliminary case control study to test this hypothesis.

\section{Methods}

The case control study was done in a tertiary care urban hospital (St. Stephens Hospital) in Delhi - the capital city of India, and the data relates to patients admitted to a tertiary post-graduate teaching hospital between $21 / 08 / 2009$ to $10 / 03 / 2011$. The department of Paediatrics is manned by 5 full time consultants and 14 resident doctors 9 of who are fully trained paediatricians working as Senior Registrars and the remaining are Senior House doctors in training for the Diplomate of the National Board in Paediatrics.

All children between the ages of one month to fourteen years who died in the hospital were included. Controls were children of matching age $( \pm$ one year except in infants where they were matched to within one month of the cases) admitted contemporaneously and who survived hospital stay. Forty events (deaths) were examined. Table 1 shows the primary system involved that necessitated hospitalization. 
Table 1: Primary System Involved in Cases (died) and Controls (survivors).

\begin{tabular}{|l|l|l|l|l|}
\hline & & $\begin{array}{l}\text { Number of } \\
\text { Patients }\end{array}$ & Cases & Controls \\
\hline & Total patients & 80 & 40 & 40 \\
\hline & $\begin{array}{l}\text { Primary system involved at the } \\
\text { time of admission }\end{array}$ & & & \\
\hline 1. & Neurological & 18 & 10 & 8 \\
\hline 2. & Respiratory & 13 & 6 & 7 \\
\hline 3. & Cardiovascular & 7 & 5 & 2 \\
\hline 4. & Gastrointestinal & 13 & 5 & 8 \\
\hline 5. & Hepatic & 6 & 3 & 3 \\
\hline 6. & Infectious & 22 & 13 & 9 \\
\hline 7. & Others & 1 & 1 & 0 \\
\hline & Progression to MODS & 15 & 15 & 0 \\
\hline & Surgical cases & 6 & 5 & 1 \\
\hline
\end{tabular}

MODS=multiorgan dysfunction syndrome

This was a retrospective analysis of routinely collected data. Ethical approval was obtained from the ethics committee of St. Stephens Hospital, Delhi for this analysis of anonymised data. The first blood count immediately after admission was analysed.

Complete blood count was done using Baeckmen Coulter electrical impedance method. Platelet count, MPV, PCT and PDW were noted.

\section{Sample size calculation}

Based on the results from the canine model $^{13}$ we anticipated a $30 \%$ increase in MPV. With local laboratory norms for MPV: $9 \mathrm{fll}$ (95\% CI 7.4-10.4) and the PCT: 0.28 $\%(95 \%$ CI $0.19-0.38)$. We calculated we would need a sample size of 34 (17 cases and 17 controls) for a study with $80 \%$ power at the $5 \%$ level of confidence. In this retrospective study, given that there is no equivalent study in children, we used twice that sample size ( 40 cases and 40 controls) which was predicted using the canine model.

\section{Statistical analysis}

Statistical analysis was done using Stata 12.1 software. Quantitative variables were compared between two groups using Wilcoxon Rank sum (Mann-Whitney) test. ROC curve analysis was used to identify the best threshold value for the measured variables and the ratios studied. Proportion of cases above and below these thresh- olds were compared between alive and dead using Chi Square Test. Using these threshold values the odds ratio with $95 \%$ confidence interval was calculated using logistic regression analysis. Multiple logistic regression was applied to identify independent predictors of mortality. All ratios were transformed into logarithmic scale for analysis.

\section{Results}

There were 40 cases and 40 controls in the study. The sex ratio (female: male) was 1:1.8 and 1:1.3 among those who died and survived respectively. The mean age among cases was 4.0 years (SD 3.86) and of controls was 3.4 years (SD 3.12). Twenty two children were below the age of 1 year, 38 children between ages of 1 and 5 years and 20 children were above the age of 5 years.

Table 2 shows the distribution of platelet count, MPV, PCT, PDW. The platelet count was significantly lower in those who died compared to those who survived. The mean platelet count among those who died was $217 \times 10^{3}$ cells $/ \mu \mathrm{L}$ and among survivors it was $312 \times 10^{3}$ cells $/ \mu \mathrm{L}$ $(p=0.01)$. Sixty seven percent of the patients with platelet count less than $245 \times 10^{3}$ cells $/ \mu \mathrm{L}$ died as against $33 \%$ with a platelet count of more than $245 \times 10^{3}$ cells $/ \mu \mathrm{L}(\mathrm{p}<0.01)$. The odds ratio for platelet count was 3.86 (95\% CI: 1.53 - 9.57). The area under the ROC curve looking at platelet count is 0.66 
Table 2: Platelet indices among cases and controls.

\begin{tabular}{|c|c|c|c|c|c|}
\hline Characteristic & $\begin{array}{c}\text { Alive } \mathbf{N}(\%) \\
\mathrm{N}=40\end{array}$ & $\begin{array}{c}\text { Dead N }(\%) \\
N=40\end{array}$ & $\mathrm{P}$ value & \multicolumn{2}{|c|}{$\begin{array}{l}\text { Odd ratio } \\
\text { (95\% C.I.) }\end{array}$} \\
\hline $\begin{array}{l}\left(x 10^{3} \text { cells } / \mu \mathrm{L}\right) \\
\text { Mean } \pm \mathrm{SD} \\
>245 \\
\leq 245\end{array}$ & $\begin{array}{r}312.72 \pm 164.57 \\
26(65.0) \\
14(35.0)\end{array}$ & $\begin{array}{r}217.42 \pm 165.98 \\
13(32.5) \\
27(67.5)\end{array}$ & $\begin{array}{r}0.01 \\
<0.01\end{array}$ & $3.86(1.53$ & $\begin{array}{r}1.00 \\
9.57)\end{array}$ \\
\hline $\begin{array}{l}\text { MPV (fl) } \\
\text { Mean } \pm \text { SD } \\
\leq 8.5 \\
>8.5\end{array}$ & $\begin{array}{r}8.7 \pm 1.63 \\
23(57.5) \\
17(42.5)\end{array}$ & $\begin{array}{r}8.7 \pm 1.82 \\
19(47.5) \\
21(52.5)\end{array}$ & $\begin{array}{l}0.92 \\
0.37\end{array}$ & $1.50(0.62$ & $\begin{array}{r}1.00 \\
3.61)\end{array}$ \\
\hline $\begin{array}{l}\text { PCT }(\%) \\
\text { Mean } \pm \text { SD } \\
>0.217 \\
\leq 0.217\end{array}$ & $\begin{array}{r}0.26 \pm 0.13 \\
24(60.0) \\
16(40.0)\end{array}$ & $\begin{array}{r}0.18 \pm 0.13 \\
15(37.5) \\
25(62.5)\end{array}$ & $\begin{array}{r}<0.01 \\
0.04\end{array}$ & $2.50(1.02$ & $\begin{array}{r}1.00 \\
6.15)\end{array}$ \\
\hline $\begin{array}{l}\text { PDW } \\
\text { Mean } \pm \text { SD } \\
\leq 16.4 \\
>16.4 \\
\end{array}$ & $\begin{array}{r}16.4 \pm 0.72 \\
21(52.5) \\
19(47.5) \\
\end{array}$ & $\begin{array}{r}16.4 \pm 1.19 \\
23(57.5) \\
17(42.5) \\
\end{array}$ & $\begin{array}{l}0.89 \\
0.65 \\
\end{array}$ & $0.81(0.34$ & $\begin{array}{r}1.00 \\
1.97) \\
\end{array}$ \\
\hline
\end{tabular}

$\mathrm{N}=$ number of patients

The mean value of Plateletcrit (PCT) among those who died was $0.18 \%$ compared to $0.26 \%$ among controls (survivors) ( $\mathrm{p}$ value $<0.01$ ). A PCT of less than $0.217 \%$ was observed in sixty two percent of the patients who died (p-value 0.04). The odds ratio of death was 2.50 (95\% CI 1.02-6.15) in patients with a PCT $<0.217 \%$. The area under ROC curve was 0.67 for PCT.

The mean MPV for those who died was $8.7 \mathrm{fl}$ and that among survivors was $8.6 \mathrm{fl}$ ( $\mathrm{p}$ value: 0.92$)$. The mean value of PDW in cases was 16.44 and among controls was 16.41 ( $\mathrm{p}$ value: 0.89 ). MPV and PDW were not statisti- cally different between the cases and the controls.

Table 3 shows the ratios of the platelet indices. The ratio for MPV/ Platelet count MPV/ PCT, PDW/Platelet count, PDW/ PCT and MPV x PDW/ Platelet count $\mathrm{x}$ PCT were significantly different in the two groups when logarithmic scale was applied. The area under ROC curve for all the above mentioned ratios was between $65 \%$ and $67 \%$. Sixty seven percent of the patients died if MPV/ PCT was more than 41.8 ( $\mathrm{p}$ value $<0.01$ ) and if PDW/ Platelet count was more than $3.86(p$ value $<0.01$ ) and $65 \%$ mortality was seen in patients with MPV/Platelet count above 3.45 ( $\mathrm{p}$ value $<0.01$ ). 
Table 3: Ratio of Platelet Indices (Cases and Controls).

\begin{tabular}{|c|c|c|c|c|c|}
\hline Characteristic & $\begin{array}{c}\text { Alive } \mathbf{N}(\%) \\
N=40\end{array}$ & $\begin{array}{c}\text { Dead N }(\%) \\
N=40\end{array}$ & $P$ value & \multicolumn{2}{|c|}{$\begin{array}{c}\text { Odd ratio } \\
\text { (95\% C.I.) }\end{array}$} \\
\hline $\begin{array}{l}\text { MPV/Plat } \\
\text { Mean } \pm \text { SD } \\
\leq 0.035 \\
>0.035\end{array}$ & $\begin{array}{r}0.07 \pm 0.17 \\
26(65.0) \\
14(35.0)\end{array}$ & $\begin{array}{r}0.17 \pm 0.35 \\
14(35.0) \\
26(65.0)\end{array}$ & $\begin{array}{r}0.02 \\
<0.01\end{array}$ & $3.45(1.38$ & $\begin{array}{r}1.00 \\
8.64)\end{array}$ \\
\hline $\begin{array}{l}\mathrm{MPV} / \mathrm{PCT} \\
\mathrm{Mean} \pm \mathrm{SD} \\
\leq 41.8 \\
>41.8\end{array}$ & $\begin{array}{r}83.1 \pm 210.39 \\
27(67.5) \\
13(32.5)\end{array}$ & $\begin{array}{r}203.9 \pm 447.57 \\
13(32.5) \\
27(67.5)\end{array}$ & $\begin{array}{r}0.01 \\
<0.01\end{array}$ & $4.31(1.69$ & $\begin{array}{r}1.00 \\
10.99)\end{array}$ \\
\hline $\begin{array}{l}\text { PDW/Plat } \\
\text { Mean } \pm \text { SD } \\
\leq 0.07 \\
>0.07\end{array}$ & $\begin{array}{r}0.13 \pm 0.32 \\
27(67.5) \\
13(32.5)\end{array}$ & $\begin{array}{r}0.34 \pm 0.79 \\
14(35.0) \\
26(65.0)\end{array}$ & $\begin{array}{r}0.01 \\
<0.01\end{array}$ & $3.86(1.53$ & $\begin{array}{r}1.00 \\
9.75)\end{array}$ \\
\hline $\begin{array}{l}\mathrm{PDW} / \mathrm{PCT} \\
\text { Mean } \pm \mathrm{SD} \\
\leq 81.3 \\
>81.3\end{array}$ & $\begin{array}{r}154.9 \pm 424.65 \\
25(62.5) \\
15(37.5)\end{array}$ & $\begin{array}{r}426.6 \pm 1130.02 \\
15(37.5) \\
25(62.5)\end{array}$ & $\begin{array}{l}0.01 \\
0.02\end{array}$ & $2.78(1.12$ & $\begin{array}{r}1.00 \\
6.87)\end{array}$ \\
\hline $\begin{array}{l}\text { Platelet Index } \\
\text { Mean } \pm \text { SD } \\
\leq 2.88 \\
>2.88\end{array}$ & $\begin{array}{r}77.5 \pm 431.34 \\
27(67.5) \\
13(32.5)\end{array}$ & $\begin{array}{r}415.1 \pm 1868.86 \\
14(35.0) \\
26(65.0)\end{array}$ & $\begin{array}{l}<0.01 \\
<0.01\end{array}$ & $3.86(1.53$ & $\begin{array}{r}1.00 \\
9.75)\end{array}$ \\
\hline
\end{tabular}

Abbreviations

MPV: Mean Platelet Volume

PDW: Platelet Distribution Width

Plat: Platelet count

PCT: Plateletcrit

Platelet Index: MPV x PDW/PCT x Plat

\section{Discussion}

We found platelet count, PCT and the ratios of MPV/ Platelet count, MPV/PCT, PDW/Platelet count, PDW/ PCT and MPV x PDW/Platelet count x PCT were significantly different for children who survived compared to those who died.

\section{Platelet count}

We found that if the count had not increased above 245 $\mathrm{x} 10^{3}$ cells $/ \mu \mathrm{L}$ the chance of death is significantly higher. In our study we found that the platelet count was lower in patients who died than those who survived. Sixty seven percent of patients died in whom the platelet count was lower than $245 \times 10^{3}$ cells $/ \mu \mathrm{L}$. The normal platelet count in healthy individuals is between $150-400 \times 10^{3}$ cells $/ \mu \mathrm{L}$. PCT is a reflection of the platelet count and platelet size, we found that the PCT in those who died was significantly different from those who survived in parallel with the platelet count findings.

Our results are similar to those by Vanderschueren and colleagues who have shown that in adults admitted in the ICU, patients who died had a lower platelet count than survivors ${ }^{6}$. Moreau et al found that on the receiver operating characteristic curve, the platelet count decline of $28.3 \%$ was associated with the best discrimination between survivors and non survivors. Thirty seven percent of those who died had a decline of more than $28.3 \%$ whereas $20.9 \%$ of survivors had this platelet decline ${ }^{19}$. Thrombocytopenia was associated with longer ICU stays, a higher incidence of bleeding events, greater transfusion requirements and higher mortality ${ }^{6,19}$. In sepsis however the platelet count increases ${ }^{20}$. It could be that the inability of the bone marrow to increase the production of platelets and release them into the circulation during sepsis maybe a risk factor for death rather than a marker of poor prognosis.

\section{Platelet Distribution Width (PDW)}

We did not find a difference between the PDW of those who died compared to survivors.

Patrick et al studied PDW in neonates with late onset sepsis. He found that PDW increased with sepsis ${ }^{18}$. We did not analyse children with sepsis separately as it was not part of the protocol for the study. 


\section{Mean Platelet Volume (MPV)}

We found no difference in the MPV between the dead and the survivors.

Van Der Leile et al have shown an increase in MPV in septicemic patients ${ }^{10}$. He postulated that with sepsis there is increased thrombocytosis and this result in increase dmegakaryocyte ploidy and an increase in MPV. Again we did not do a subgroup analysis of patients with septicaemia.

\section{MPV/PCT}

We found that the ratio of MPV / PCT was a better predictor of mortality than platelet count or plateletcrit by themselves. This suggests that although there was no statistically significant difference in MPV and PDW between those who survived and those who died, there must have been subtle increase in the MPV and a correspondence decrease in PCT such that the ratio of MPV / PCT was more meaningful as an indicator of survival than either of the parameters taken alone. This could have resulted from an increase in the production of platelets and the release of immature and larger platelets into the circulation to meet the increase demands.

We found on multiple regression analysis that the ratio of MPV/PCT, PDW/Platelet count and MPV/Platelet count were predictors of mortality with the Odds ratio of $4.31,3.86$ and 3.45 respectively.

We had hypothesised that these ratios would be increased in non survivors. This is the first study where these parameters have been examined as a ratio.

Ours is a retrospective case control study of data and has all the attendant limitations of a retrospective study. Further prospective studies are needed to confirm these findings. We used the first blood sample after admission. Furthermore we studied only single values of these parameters, and have not investigated the trend during the course of illness within the hospital. It is possible that counts may vary with the duration of illness prior to admission. It is also a drawback that we have not taken into consideration the duration of illness prior to hospitalisation.

In the studies for PRISM III score looking at multiple factors that predict mortality in sick children admitted to intensive care the best indicators were abnormal pupillary reflexes [OR 9.9 (95\% CI, 3.5-28.4)], acidosis [OR
3.1 (95\% CI, 2.0-4.9)], blood urea nitrogen concentration [OR 1.03 (95\% CI, 1.01-1.04)], and white blood cell count OR 1.02 (95\% CI, 1.01-1.03)(21). The odds ratio of 4.31 that we have shown for MPV/PCT, 3.86 for PDW/ Platelet count and 3.45 for MPV/Platelet count suggests that these are likely to have a good predictive ability if included in a severity of illness scoring system. This may be used in scoring systems to predict hospital survival. Further studies are needed to see if it can improve predictive ability of existing severity of illness scoring systems.

\section{Conclusion}

The MPV/PCT, PDW/Platelet count and MPV/Platelet count, in the first sample after admission in this case control study were predictors of mortality and could predict $65 \%$ to $67 \%$ of deaths accurately.

\section{Conflict of interests}

None declared.

\section{References}

1. Féry-Lemonnier E, Landais P, Loirat P, Kleinknecht D, Brivet F. Evaluation of severity scoring systems in ICUs-translation, conversion and definition ambiguities as a source of inter-observer variability in Apache II, SAPS and OSF. Intensive Care Med. 1995 Apr;21(4):356-60.

2. Yeh TS, Pollack MM, Ruttimann UE, Holbrook PR, Fields AI. Validation of a physiologic stability index for use in critically ill infants and children. Pediatr. Res. 1984 May;18(5):445-51.

3. Pollack MM, Ruttimann UE, Getson PR. Pediatric risk of mortality (PRISM) score. Crit. Care Med. 1988 Nov;16(11):1110-6.

4. Sun D, Aikawa N. The natural history of the systemic inflammatory response syndrome and the evaluation of SIRS criteria as a predictor of severity in patients hospitalized through emergency services. Keio J Med. 1999 Mar;48(1):28-37.

5. Bhal S, Tygai V, Kumar N, Sreenivas V, Puliyel JM. Signs of inflammation in children that can kill (SICK score): preliminary prospective validation of a new noninvasive measure of severity-of-illness. J Postgrad Med. 2006 Jun;52(2):102-5.

6. Vanderschueren S, De Weerdt A, Malbrain M, Vankersschaever D, Frans E, Wilmer A, et al. Thrombocytopenia and prognosis in intensive care. Crit. Care Med. 2000 Jun;28(6):1871-6. 
7. Gulcu E, Durmaz Y, Karabay O. Effect of severe sepsis on platelet count and their indices. African Health Sciences. 2013 Jun;13(2): 333-338.

8. Ghosh TK, Khan N, Malik A. Platelet auto-antibodies in septicaemic patients. Indian J Pathol Microbiol. 1999 Jan;42(1):31-5.

9. Greinacher A, Selleng K. Thrombocytopenia in the intensive care unit patient. Hematology Am Soc Hematol Educ Program. 2010;2010:135-43.

10. Van der Lelie J, Von dem Borne AK. Increased mean platelet volume in septicaemia. J. Clin. Pathol. 1983 Jun;36(6):693-6.

11. Babu E, Basu D. Platelet large cell ratio in the differential diagnosis of abnormal platelet counts. Indian J Pathol Microbiol. 2004 Apr;47(2):202-5.

12. Wiwanitkit V. Plateletcrit, mean platelet volume, platelet distribution width: its expected values and correlation with parallel red blood cell parameters. Clin. Appl. Thromb. Hemost. 2004 Apr;10(2):175-8.

13. Taniguchi T, Takagi D, Takeyama N, Kitazawa Y, Tanaka T. Platelet size and function in septic rats: changes in the adenylate pool. J. Surg. Res. 1990 Nov;49(5):400-7. 14. Yilmaz Z, Eralp O, Ilcol YO. Evaluation of platelet count and its association with plateletcrit, mean platelet volume, and platelet size distribution width in a canine model ofendotoxemia. Vet Clin Pathol. 2008
Jun;37(2):159-63.

15. Nelson RB 3rd, Kehl D. Electronically determined platelet indices in thrombocytopenic patients. Cancer. 1981 Aug 15;48(4):954-6.

16. Becchi C, Al Malyan M, Fabbri LP, Marsili M, Boddi V, Boncinelli S. Mean platelet volume trend in sepsis: is it a useful parameter? Minerva Anestesiol. 2006 Sep;72(9):749_ 56.

17. Guida JD, Kunig AM, Leef KH, McKenzie SE, Paul DA. Platelet count and sepsis in very low birth weight neonates: is there an organism-specific response? Pediatrics. 2003 Jun;111(6 Pt 1):1411-5.

18. Patrick CH, Lazarchick J. The effect of bacteremia on automated platelet measurements in neonates. Am. J. Clin. Pathol. 1990 Mar;93(3):391-4.

19. Moreau D, Timsit J-F, Vesin A, Garrouste-Orgeas M, De Lassence A, Zahar J-R, et al. Platelet count decline: an early prognostic marker in critically ill patients with prolonged ICU stays. Chest. 2007 Jun;131(6):1735-41.

20. Fouzas S, Mantagou L, Skylogianni E, Varvarigou A. Reactive thrombocytosis in febrile young infants with serious bacterial infection. Indian Pediatr. 2010 Nov;47(11):937-43.

21. De León ALP-P, Romero-Gutiérrez G, Valenzuela CA, González-Bravo FE. Simplified PRISM III score and outcome in the pediatric intensive care unit. Pediatr Int. 